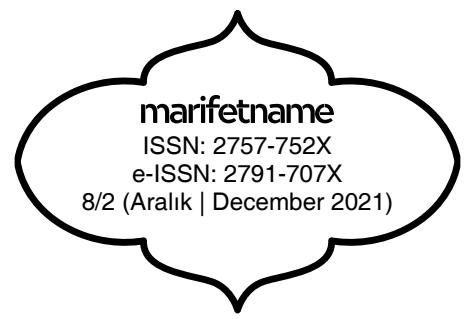

Georg Simmel'in Din Teorisinin Temel Yaklaşımları

Basic Approaches to the Theory of Religion by Georg Simmel

\title{
Ahmet ASLAN
}

Dr. Öğr. Üyesi., Erzincan Binali Yıldırım Üniversitesi Fen Edebiyat Fakültesi, Sosyoloji Bölümü, Erzincan/Türkiye

Assist. Prof., Erzincan Binali Yıldırım University, Faculty of Arts and Sciences, Department of Sociology, Erzincan/Turkey

ahmet.aslan@erzincan.edu.tr|orcid.org/ 0000-0003-1657-9662

DOI: 10.47425/marifetname.vi.995309

Makale Bilgisi | Article Information

Makale Türü | Article Type: Araştırma Makalesi | Research Article

Geliş Tarihi | Received: 14 Eylül / September 2021

Kabul Tarihi | Accepted: 14 Kasım / November 2021

Yayın Tarihi | Published: 30 Aralık / December 2021

\section{Attf $\mid$ Cite as}

Aslan, Ahmet. "Georg Simmel'in Din Teorisinin Temel Yaklaşımları [Basic Approaches to the

Theory of Religion by Georg Simmel]" Marifetname.8/2 (Aralık/2021), s. 503-531.

\section{İntihal | Plagiarism}

Bu makale, iThenticate aracilı̆̆ıyla taranmış ve intihal tespit edilmemiştir.

This article, has been scanned by iThenticate and no plagiarism has been detected.

\section{Copyright $(9$}

Published by Siirt University Faculty of Divinity. Siirt/Turkey.

web: https://dergipark.org.tr/tr/pub/marifetname

mail: sifdergisi@gmail.com 


\section{Georg Simmel'in Din Teorisinin Temel Yaklaşımları}

Öz: Günümüz sosyoloji teorisinde fikirleri yeniden keşfedilen Simmel'ın din teorisi ve din sosyolojine katkısı ise nispeten ihmal edilmiştir. Onun yaklaşımının temelinde sosyal ve tarihsel bir fenomen olarak din ile insanın doğasında yer alan dinselliğe dayalı öznel dindarlık ayrımı yer almaktadır. Simmel'a göre "belirli bir manevi nitelik" veya "ruhun tutumu" olarak insan doğasında yer alan dinsellik, insanın dünyaya bir bütün olarak bakmasına ve dinin kültürel bir ürün olarak oluşmasına imkân tanımaktadır. $O$, geliştirdiği doğal dinsellik eğilimi (religioid) kavramıyla dinin sanat gibi farklı alanlarda da yansitılabilen bireysel temelini tespit etmektedir. Simmel'a göre bu eğilim insanlar arası etkileşimlerle şekillenerek dine dönüşmektedir. Dini insan etkileşimleri ile temellendirmeye çalışan Simmel, insanın birçok ilişkisinin özünün dinî karakterde olduğunu savunmuştur. Örneğin inanç ona göre bireyler arasında bir ilişki biçimidir ve zamanla bu inançtan Tanrı fikri doğmaktadır. Türkçe literatürde Simmel'ın din teorisine ve din sosyolojine katkısına dair bir makale dışında bütünlüklü bir çalışma bulunmamaktadır. Büyük ölçüde Simmel'ın dine ilişkin metinlerinin orijinal dilden yeniden okunmasını esas alan bu makale, onun din sosyolojine katkısını; din anlayışını, din ile dindarlık ve din ile kültür ilişkisine dair yaklaşımlarını betimlemektedir.

Anahtar kelimeler: Din Sosyolojisi, Din Teorisi, Din, Dindarlık, Georg Simmel.

\section{Basic Approaches to the Theory of Religion by Georg Simmel}

Abstract: Simmel's contribution to the theory of religion and sociology of religion, whose ideas were rediscovered in contemporary sociological theory, has been relatively neglected. The basis of his approach is the distinction between religion as a social and historical phenomenon and subjective religiosity based on religiosity in human nature. According to Simmel, religiosity in human nature as "a certain spiritual quality" or "attitude of the soul" allows people to look at the world as a whole and religion to be formed as a cultural product. He identifies the individual basis of religion, which can be reflected in different fields such as art, with the concept of natural religiosity he developed. According to Simmel, this tendency is shaped by interactions between people and turns into religion. Trying to ground religion with human interactions, Simmel argued that the essence of many human relations is religious in character. For example, according to him, belief is a form of relationship between individuals, and in time, the idea of God emerges from this belief. There is no comprehensive study in Turkish literature except for an article on Simmel's contribution to the theory of religion and 
sociology of religion. Based largely on the re-reading of Simmel's texts on religion from the original language, this article focuses on his contribution to the sociology of religion; It describes the understanding of religion, their approach to the relationship between religion and religiosity and religion and culture.

Keywords: Sociology of Religion, Theory of Religion, Religion, Religiosity, Georg Simmel.

\section{Giriş}

"Manevi bir gerçeklik olarak din; bitmiş bir şey, katı bir madde değil; rivayet edilen içeriğin sarsılmazliğına rağmen her rubun ve her anın kendisi üretmesi gereken, yaşayan bir süreçtir. Bu sürȩ̧; tıpkı sürekli değişen su damlacıklarının gökkuşağııın sabit görüntüsünü yaratması gibi dinsel olarak mevcut olanı, hareketlerini tekrar tekrar șekillendirmek zorunda olan duygu ırmağına sürekli çekmeyi gerektirmektedir. Iște dinin gü̧̧ ve derinliği burada yatar."

George Simmel

Sosyolojinin kurucularının tümünün merkezi temalarının başında din gelmektedir. Onların din ile ilgilenmeleri, dinin etkin olduğu geleneksel toplum düzeninden onun etkinliğinin zayıfladığı endüstriyel-kapitalist topluma geçişte yaşanan büyük toplumsal değişmelerin bilimi olarak beliren sosyolojiye bütünlük kazandırma çabasının vazgeçilmez bir parçası olmuştur. Weber'in kapitalizmin dini köklerine ilişkin tarihsel araştırması; ${ }^{1}$ Durkheim'ın karmaşık toplumların sosyal entegrasyonu için mekanik dayanı̧̧ma $^{2}$ ile totemik ritüellerin önemi ${ }^{3}$ üzerindeki ısrarı; Marx'ın dini mevcut düzenin ideolojik yeniden üretimine katkıda bulunan, katlanılmaz olanı katlanılır kılan bir yanlış bilinç biçimi olarak görmesi ${ }^{4}$ hep aynı çabanın sonuçları olarak belirmektedir.

Sosyoloji; 20. yüzyılın başlarında büyük ahlak ve siyaset felsefesi gele-

1 Max Weber, Protestan Ablakı ve Kapitalizmin Ruhu, çev. Zeynep Gürata (İstanbul: Ayraç Yayınlar1, 1999).

2 Emile Durkheim, Toplumsal İşbölümü, çev. Özer Ozankaya (İzmir: Cem Yayınevi, 2018).

3 Emile Durkheim, Dinsel Hayatın İlkel Biçimleri, çev. Fuat Aydın (Ankara: Kalkan Matbaacılık, 2011).

4 Vincent Geoghegan, "Religion and communism: Feuerbach, Marx and Bloch", The European Legacy, 9/5, (2004), 588. 
neği doğrultusunda döneminin ahlaki, politik ve felsefi sorunlarıla hayati bağlantısını kaybetmeden özerk bir disiplin olmaya çalışmı̧tır. Bu süreçte dine odaklanılmıştır. Zira din, toplumsal hayata dair çeşitli meydan okumalar içermektedir. Dinin bu doğasının sosyolojik bakış açısından sorgulanması ve test edilmesi ihtiyacı klasiklerin dini merkezî tema olarak seçmelerini açıklar nitelikte görünmektedir. Hatta eğer "Tanrı́nın toplumsal bir inşa olduğu", kolektif inançların toplumsal yaşamı etkilediği ampirik olarak analiz edilebilse bu sosyolojinin rüştünü ispatı olarak değerlendirilecekti. Bu doğrultuda din sosyolojisi; dini olduğu gibi değil sekülerleşen toplumlardaki sosyal eylemle ilişkisi açısından analiz eden, seküler bir sosyoloji olarak doğmuştur. ${ }^{5}$

Sosyolojinin Comte, Durkheim, Simmel, Weber, Sorokin ve Parson gibi büyük teorisyenleri, aynı zamanda din sosyolojisinin de büyük temsilcileridir.6 Bunlardan biri olarak kabul görmekle birlikte Simmel'ın din sosyolojisine katkısı gözden kaçabilmektedir. Önde gelen Simmel araştırmacılarından biri olan Volkhard Krech, bu durumu onun din teorisinin felsefî yönlerinin ağrilıkta olmasına bağlamakta ve onu Weber ve Durkheim ile birlikte çalışmalarında din temasına merkezî önem veren klasikler arasında değerlendirmektedir. ${ }^{7}$ Bununla birlikte Simmel'in din teorisi, diğer ikisinin din sosyolojileri kadar geniş çapta kabul görmemiştir.

Başlangıcında özsel, ardından işlevsel din tanımlarına yoğunlaşan, kimi zaman "tanım erteleyen" tavırlar sergileyen din sosyologlarının etkisinde kalan din sosyolojisi, günümüzde genellikle geniş ve görece belirsiz din kavramını varsaymaktadır. Dinin tanımına ilişkin tüm tartışmalardan sonra din artık hayatın geri kalanından ayrı bir şey olarak değil, insanın yaşam

5 Volkhard Krech- Hartmann Tyrell, Religionssoziologie um 1900 (Würzburg: Ergon, 1995); Frederic Vandenberghe, "Immanent transcendence in Georg Simmel's sociology of religion", Journal of Classical Sociology 10/1, (February 2010).

6 Roberto Cipriani, Din Sosyolojisi, Tarih ve Teori, haz: Ali Coşkun (İstanbul: Rağbet Yayınları, 2014), 13.

7 Volkhard Krech, Georg Simmels Religionstheorie (Religion und Aufklärung 4) (Tübingen: Mohr Siebeck, 1998); Volkhard Krech, “Die 'Soziologie der Religion'- neu gelesen”, Georg Simmel und das Leben in der Gegenwart, ed. Rüdiger Lautmann, Hanns Wienold (Wiesbaden: Springer, 2018). 
biçiminin ayrılmaz bir parçası olarak anlaşılmaktadır. Bu doğrultuda günümüzde din sosyolojisi metodolojik bir bilinemezcilik temelinde çalışmakta; teolojilerin aksine, hakikat sorusundan vazgeçmekte, böylece her dinin hakikat iddialarını, "inanççı" din tanımlarını paranteze almaktadır. ${ }^{8}$ Georg Simmel, geçen yüzyılın başlarında "dindarlık olarak din” yaklaşımı ve genel din teorisiyle günümüz din sosyolojinin karar kıldığı zikredilen hususlara oldukça erken bir dönemde öncülük etmektedir.

İşlediği konuların ve ilişkili malzemenin dağınıklı̆̆ı, uyumlu genel açıklamaların azlığı ve akademik geleneğe aykırı duruşuna rağmen yeni fikirlerin ve kuramların mucidi, modernlik sosyoloğ ${ }^{9}$ olarak nitelenen Simmel'ın din teorisi, günümüzün din tartışmalarına katkı sağlayacak güncelliğini korur görünmektedir. Bu çalışmanın amacı din teorisi Türkçe literatürde yeterince işlenmemiş olan ${ }^{10}$ Simmel'ın din teorisinin temel yaklaşımlarını olabildiğince doğrudan onun yazılarından yola çıkarak betimlemektir. $\mathrm{Bu}$ amaçla önce Simmel'ın entelektüel portresi çizilerek dinle ilgili yazıları tanıtılmış, ardından onun sosyolojisinin ana hatları ve dinin bu sosyolojideki yeri ve din sosyolojisine katkısı tespit edilmeye çalışılmış, sonra da sırasıyla din ile dindarlık, din ile kültür ve din ile sosyalleşme arasındaki ilişkiye dair yaklaşımları ayrı ayrı başlıklar altında incelenmiştir.

\section{Georg Simmel'in Entelektüel Portresi ve Dine Dair Çalışmaları}

Georg Simmel (1858-1918), Berlin'in bohem aydınlar topluluğunun tipik, ancak kendine has özellikleriyle özgün bir şahsiyetiydi. Yahudilikten Katolikliğe geçen zengin bir iş adamı olan babanın ve Protestan bir annenin yedinci çocukları olarak doğdu. Genç yaşlarındayken babasını kaybetmesi,

8 Winfried Gebhardt, "Religionssoziologie", Handbuch Spezielle Soziologien, ed. Georg Kneer, Markus Schroer (Wiesbaden: VS Verlag für Sozialwissenschaften, 2010), 394.

9 George Ritzer, Klasik Sosyoloji Kuramları, çev. Himmet Hülür (Ankara: De Ki, 2011); David Frisby, "Georg Simmel: Modernitenin İlk Sosyoloğu”, çev. Elçin Gen, Modern Kültürde Çatış$m a$, haz. Elçin Gen (İstanbul: İletişim Yayınları, 2015), 7.

10 Georg Simmel'ın din teorisi ile doğrudan alakalı yayımlanmış Türkçe bir kitap bulunmamaktadır. Konuyla ilgili yayımlanan tek makale ise "Georg Simmel'in Bakı̧ Açısından Modernite ve Din” (2019) başlıklı bir yüksek lisans tezinden üretilmiştir. Abdulvahap Taştan- Mehmet Aksoy, "Georg Simmel'in Sosyolojik ve Psikolojik Bakış Açılarından Din ve Dindarlık Anlayışı”, Bilimname, 2020 / 41 (Mayıs, 2020). 
otoriter olduğu için annesiyle ilişkisinin mesafeli oluşu Simmel'ın güvenli bir aile ortamından mahrum kalmasına sebep oldu. Böylece o, marjinallik ve güvensizlik duygusunu erken yaşlarda yaşadı.

Berlin Üniversitesi'nde döneminin önemli akademik isimlerinden tarih ve felsefe okuyan Simmel, 1881'de "Kant' ın Maddenin Doğasına İlişkin Farklı Görüşlerinin Sunumu ve Değerlendirmeleri” başlıklı felsefe doktorasını tamamladığında tarihten felsefeye ve psikolojiden sosyal bilimlere geniş bir alana aşinayd. Mantık, felsefe tarihi, etik, sosyal psikoloji ve sosyoloji dersleri veren Simmel; başkaları yanında Kant, Schopenhauer, Darwin ve Nietzsche üzerine konferanslar verdi. Böylelikle sosyolojide olduğu kadar metafizikte de yeni eğilimleri araştırırdı. Yüksek popülerliğe erişen Simmel, zamanla hem öğrenciler hem de Berlin'in kültürel seçkinleri için önde gelen entelektüellerden biri oldu. Kırklı yaşlarında ise ünü, Avrupa ülkelerine ve Robert Park gibi öğrencileri sayesinde Amerika'ya kadar yayıld.

Simmel, "toplum"un (Gesellschaft) yerine "sosyalleşme"nin (Vergesellschaftung) izini sürmeyi tercih etmiş; ahenkli, işlevsel, bütüncül sosyal yapı veya düzeni esas almak yerine parçalı ve çoğul olan sosyalin sosyolojisini inşa etmek istemiştir. Böylelikle o spekülatif, felsefi, keyfi ve fragmanlara yönelen yaklaşımıyla döneminin epistemik cemaatine ters düşmüştür. Çok üretken bir yazar olarak üç yüzden fazla makale; felsefe, etik, sosyoloji ve kültürel eleştiri alanlarında on beş büyük eser ve daha az önemli altı kitap yayımlayan Simmel, tutarlı bir sosyolojik veya felsefi sistem geliştiremediği için öngördüğü gibi bir okul oluşturamadan hayata veda etmiştir. Çok okunmuş ama kabul görmemiş, çok yazmış ama akademide tutunamamıştır. Ancak Robert Park, Georg Lukacs, Ernst Bloch, Martin Buber, Max Scheler ve Bernhard Groethuysen gibi birbirine benzemeyen birçok kişi ondan ilham almıştır. Alman sosyologlar Karl Mannheim, Alfred Vierkandt, Hans Freyer ve Leopold von Wiese de Simmel'in çalışmalarından etkilenmiştir. Theodor Adorno, Max Horkheimer ve Frankfurt neo-marksist sosyoloji okulunun diğer temsilcileri, özellikle kitle kültürü ve kitle toplumu eleştirilerinde ona çok şey borçludur. ${ }^{11}$ 
Protestan olarak vaftiz edilen, nikâhı kilisede kıyılan Simmel, Dünya Savaşı sırasında Kilise'yi terk etmiştir. Simmel kültürü, görünümü ve tavırları açısından Yahudi olmakla birlikte Yahudiliği Hıristiyanlıktan aşağı gören seküler-kültürel Protestan olarak yaşamıştır. Felsefi yaklaşımları sebebiyle bazı araştırmacılar, din ve mistisizmin onun en derin dürtülerinden olduğunda 1srar etmiş,12 bazıları da onun yazılarının teolojik boyutunu estetik boyutundan daha üstün olarak değerlendirmiştir.13

Simmel'ın "Die Religion" (din) adlı monografisi ilk olarak 1906'da Martin Buber'nın Die Gesellschaft. Sammlung Sozialpsychologischer Monographien adlıserisinin ikinci cildi olarak yayımlanmıstır. 1912'de ise Die Religion'un genişletilmiş baskısı yayımlanmıştır. Monografi, Simmel'ın 1898'te kaleme aldı̆̆g "Zur Soziologie der Religion”(Din Sosyolojisi Katkı) ve başka kısa din felsefesi metinlerinin üzerine inşa edilmiş görünmektedir. Yine monografi Simmel'ın 1902/03'te kaleme aldığı "Vom Heil der Seele" (Ruhun Kurtuluşu Hakkında) adlı metnin pasajlarıyla zenginleştirilmiştir. Simmel bu dönemde din konusunda başka metinler de kaleme almıştır: "Beiträge zur Erkenntnistheorie der Religion 1902" (Dinin Epistemolojisine Katkilar), "Vom Pantheismus 1902/1903” (Panteizm Hakkında), “Die Gegensätze des Lebens und der Religion 1904/1905" (Hayatın ve Dinin Karşıtllkları), "Ein Problem der Religionsphilosophie 1905” (Din Felsefesinin Bir Sorunu). Religion'un 1912'deki genişletilmiş ikinci baskısı ilkinden yaklaşık dörtte bir oranında daha hacimlidir. Simmel iki baskı arası dönemde, 1911'de "Die Persönlichkeit Gottes. Ein philosophischer Versuch" (Tanrı́nın Kişiliği. Felsefi Bir Girişim) ve "Das Problem der religiösen Lage" (Dinsel Durum Sorunu) başliklı iki din felsefesi metni yayımlamıştır. ${ }^{14}$

Dine dair çok çeşitli metinler yayımlayan ve hemen hemen bütün düşüncelerini "Din" monografisinin ikinci versiyonuna yansitan Simmel, bu eserini ta-

12 Margarete Susman, Die geistige Gestalt Georg Simmels, (Tübingen: Mohr + Bdd, 1959).

13 David Frisby, Modernlik Fragmanları Simmel, Kracauer ve Benjamin’in Eserlerinde Modernlik Teorileri, çev. Akın Terzi (İstanbul: Metis Yayınları, 2012); Vandenberghe, "Immanent transcendence in Georg Simmel's sociology of religion".

14 Volkhard Krech, “Georg Simmel: Die Religion (1906/1912)”, Schlüsselwerke der Religionssoziologie. Veröffentlichungen der Sektion Religionssoziologie der Deutschen Gesellschaft für Soziologie. haz. ChristelGärtner, Gert Pickel (Wiebaden: Springer VS, 2019), 109-110. 
mamlanmamış olarak değerlendirmiştir. ${ }^{15}$ Simmel insanın ölümlü varoluşunu karakterize eden karşıtlıklar ve bölünmelerin ardında bir birlik arayışı içinde olmuş, dini de bu birlik özleminin bir ifadesi olarak görmüştür. $\mathrm{O}$, gerçekliğin ötesinde salt yaşamı aşan, tüm anları kapsayan ve ona birliğini veren bir şey olduğunu ima etmektedir. Bununla birlikte o; baştan sona agnostik bir tutum sergilemekten de geri durmamakta ne Tanrı'ya inandığını ne de onu açıkça inkâr ettiğini beyan etmektedir. Ancak onun Tanrı hakkında konuşmaması, ilahi olana ilişkin genel yargısıyla da ilişkilendirilebilir. Ona göre ilahi olan her ne kadar deneyimlenebilir olsa da tarif edilemez, tanımlanamaz. Onda "olumsuz teolojiye” yönelik güçlü eğilimler bulunmaktadır. Buna göre Tanrı tamamen "öteki”dir ve onun ne varlığı ne yokluğu savunulabilir. Zira insandan o kadar farklıdır ki onun kavramsallaştırılması hayal dahi edilemez. ${ }^{16}$

\section{Simmel'in Sosyoloji Anlayışında Dinin Konumu}

Modernitenin ilk sosyologu ${ }^{17}$ olarak nitelenen Georg Simmel, çeşitli fikir ve kuramsal yaklaşımların öncüsü olmakla birlikte bütünlüklü ve uyumlu bir çerçevesi bulunmayan bölük pörçük eserler bırakmakla eleştirilmektedir. Ancak onun yaklaşımlarının sosyoloji kuramı üzerindeki etkileri 20. yüzyılın sonunda başta "bu gerçekten benim kitabım” dediği Paranın Felsefesi’nin zamanla öneminin artması ve düşüncelerinin postmodern toplum kuramı bağlamında yeniden yorumlanması gibi sebeplerle artmıştır. Simmel; çatışma kuramı yanında küçük grup araştırması, sembolik etkileşimcilik ve alışveriş kuramının gelişimindeki rolü göz ardı edilemez. Zira onun sosyoloji anlayışı; birincil biçimlerin ve etkileşim tiplerinin araştırılmasını öncelemektedir. ${ }^{18}$

Simmel'in eserlerinde genel olarak dört ilgi düzeyi bulunmaktadır: toplumsal yaşamın psikolojik bileşenlerine dair varsayımlar, kişilerarası ilişkilerin sosyolojik bileşenlerinin araştırılması, kendi döneminin toplumsal/ kültürel "ruh" yapısı ve ondaki değişimler, yaşamın en üst metafizik ilkeleri. Bu sonuncu düzeye ait ebedi doğruluklar onun eserlerinin tümünü ve dünyanın geleceğine bakışını etkilemektedir. Bu bütünlük içinde toplumun

15 Krech, “Georg Simmel: Die Religion (1906/1912)”, 110.

16 Vandenberghe, "Immanent transcendence in Georg Simmel's sociology of religion”, 7.

17 David Frisby, "Georg Simmel: Modernitenin İlk Sosyoloğu”.

18 David Frisby, Georg Simmel (London: Routledge, 2002); Ritzer, Klasik Sosyoloji Kuramları. 
bağımsız bir bilimin özerk nesnesi olması Simmel'a göre, onu oluşturan bireysel öğelerin toplamından yeni bir oluşumun ortaya çıkmasına bağlldır. Toplumsal gerçekliğin çoklu düzeyleri Simmel'ın sosyolojine psikolojik değişkenlerle, etkileşim biçimlerinin birleştirildiği "saf" sosyoloji; insan tarihinin toplumsal ve kültürel ürünlerini ele alan, gruba ve toplumların ve kültürlerin yapısı ve tarihine yönelik büyük-ölçekli ilgileri içeren "genel” sosyoloji ve insanlığın temel doğası ve kaçınılmaz yazgısına odaklanan "felsefî" sosyoloji olarak yansımaktadır. ${ }^{19}$

Çeşitli güdü, amaç ve çıkarlarıyla etkileşime (Wechselwirkung) giren bilinçli bireyler veya gruplar, Simmel'ın sosyolojisinde sosyal hayatın temelini oluşturmaktadır. Sosyal ve kültürel yapılar kendilerine özgü bir varoluşa sahip olmakla birlikte belli bir bilince göre hareket etmektedir. Bu doğrultuda Simmel, etkileşim içindeki insan tipleri kadar etkileşim formlarını da incelemektedir. Bu bakışla gerçek dünya sayısız olay, eylem ve etkileşimden oluşmaktadır. İnsanlar, hayata ilişkilerini yansıtan belli formlar dayatmaktadır. Onun sosyolojisinde yabanc1, yoksul, cimri, müsrif, maceraperest ve asilzade sosyal tipe; mübadele, çatı̧̧ma, fahişelik ve sosyallik ise sosyal formlara örnek teşkil etmektedir. Böylelikle Simmel, toplumun atomları arasındaki etkileşimi inceleyen gündelik hayatın ve somut ilişkilerin sosyoloğu olmaktadır. Onun sosyolojisi; insan eylemlerinden bağımsız toplum tasavvuru taşıyan klasik sosyolojinin karşısında toplumu, sosyalleşmeyi bizzat gerçek kılan bireyler arası kompleks ilişkiler ve etkileşimler ağı olarak görmektedir. Ona göre eğer "sadece ve sadece toplumu konu alacak bir bilim olacaksa, bu bilimin münhasıran bu etkileşimleri, bu toplumlaşma tür ve biçimlerini incelemesi" gerekmektedir. ${ }^{20}$ Simmel, hayatın her ayrıntısında hayatın bütününü bulma ihtimalini arayışının temel motivasyonu olarak benimsemiştir. Her şey herhangi bir şekilde başka bir şeyle etkileşir, ilkesi onun "ilişkici" oluşunu açıklamaktadır. Bu doğrultuda Simmel için adalet, din ya da bilginin anlamı, değeri ve özü bunların tarihsel olarak gerçekleşme tarzlarının ötesinde yatmaktadır. ${ }^{21}$

19 Ritzer, Klasik Sosyoloji Kuramları, 267.

20 Georg Simmel, Bireysellik ve Kültür, çev. Tuncay Birkan (İstanbul: Metis Yayınları, 2009), 48.

21 Georg Simmel, Die Religion, (b.y:: Dearsbooks Europeachische Literatur Verlag Gmbh, 2014), 18. 
Simmel'ın sosyolojisi; çok nedenli, çok eksenli, olgu ile değeri bütünleştiren, toplumsal fenomenler arasında sabit ayrım çizgileri varsayımını reddeden, çatışma ve tutarsızlıklara yoğunlaşan diyalektik bir karakter taşımaktadır. ${ }^{22} \mathrm{O}$, çalışmalarında daha çok birey ile bireylerin inşa ettikleri daha büyük toplumsal ve kültürel yapılar arasında gelişen çatışma ve çelişkilere yoğunlaşmaktadır. Zamanla söz konusu yapılar bireyin denetiminden uzaklaşarak bağımsızlaşmaktadır. Bu noktada Simmel'ın bireysel ve nesnel kültür ayrımı açıklayıcı bir işlev görmektedir. Sosyal dünya, kültürü yaratarak kendisini var eden aktörler üzerinde zamanla tahakküm kurmaya başlar ve sonunda kendine ait bağımsız bir varoluş kazanır. Ancak insanın bu kültür yaratma gücü, tarihin akışı içinde, kültürün unsurları kendilerine has bir mantık ve yasallık edindiğinden kültüre boyun eğmek zorundadır. Ruhun yaratıcı hareketi sanki kendi ürünü tarafindan öldürülmektedir. Ulaşım araçları, bilimsel ürünler, felsefî ve hukukî sistemler, teknoloji, güzel sanatlar ve ahlak kuralları gibi şekillerde nesnelleşen kültür; modernleşmenin yükselişiyle etki alanını genişletmiştir. Simmel bireysel kültürün hakimiyetinde bir dünya arzulasa da böyle bir arzunun gerçekleşmeyeceğinin farkındadır. Nihayetinde söz konusu olan, özün ve varoluşun derinlerinden fişkıran güçlerin, kültürün özünü ve varoluşunu mahvettiği bir trajedidir. Sanki ruhun yaratıcı hareketi kendi ürünü tarafından öldürülmektedir.23

Simmel'ın sosyolojiye en büyük katkısı toplumsal etkileşimin anlaşılmas1na yönelik vurgu ve incelemeleridir. $\mathrm{O}$, soruna mikro açıdan yaklaşarak "birkaç bireyin etkileşime girdiği yerde toplumu” görmektedir. Bu etkileşimler daima belli güdü ya da amaçlar gözetilerek gerçekleşmektedir. Cinsel, dinî ya da sadece yakınlık kurmaya yönelik çeşitli güdülerle ve savunma, saldırı, oyun, kazanç, yardım ya da eğilim gibi sayısız amaçla bireyler birbirleriyle etkileşime girmektedir. Böylelikle bireyler başkalarıyla birlikte, onlar için ya da onlara karşı hareket etmekte, onlarla bir bağ kurmakta, onları etkilemekte ve onlardan etkilenmektedirler. Bu etkileşimlerle bir birlik, toplum meydana gelmektedir. Simmel bireylerde bulunan ve başkaları üzerinde etki oluşturabilecek her türlü güdü, çıkar, amaç, eğilim, ruhsal durum ve hareketi toplum-

23 Simmel, Bireysellik ve Kültür, 341. 
laşmanın malzemesi olarak görmektedir. Ancak bu malzeme ona göre kendi başına toplumsal değildir. Örneğin açlık, aşk, iş, dindarlık ya da teknoloji "birlikte ve birbiri için var olmanın özgül biçimlerine" dönüştürdüklerinde toplumlaşma etkenleri olmaktadır. Ona göre toplumlaşma; güdüsel ya da idealistçe, geçici ya da kalıcı, bilinçli ya da bilinçsiz, nedensel ya da amaçlı oluşturulan birlik biçimleridir. ${ }^{24}$ Kısacası Simmel, Durkheim'dan farklı olarak sosyolojisine küçük-ölçekli etkileşimleri odak olarak seçmiştir.

Simmel'ın sosyoloji anlayışında toplumu oluşturan unsurların gerçek birimler olması gerekmez. "Birey ve toplum hem tarihsel bilgi hem de değerlendirme ve standartlaştırma için metodolojik kavramlardır- ister olayların ve koşulların verililiğini kendi aralarında bölsünler, ister bizim hemen kavrayamadığımız birliğini bölsünler..."25 Onun bakışıla bunlar ontolojik nicelikler değil, buluşsal amaçlar için tamamlayıcı bir terim çifti olarak kullanılmak içindir. O, birey ve toplum ilişkisine dinamik bir süreç olarak yaklaşmaktadır.

Simmel, sistematik bir din teorisi yazmamasına rağmen onun eserlerinde sosyoloji, kültür teorisi ve yaşam-felsefesi (Lebensphilosophie) katmanlarına dayanan bir din teorisi bulmak mümkündür. Böyle bir okumada Simmel'ın parça ile bütün arasında kurduğu ilişki üzerinden onun din teorisine yaklaşılabileceği görülmektedir. $\mathrm{O}$; söz konusu yaklaşımla toplumsalı "birey-toplum" ilişkisi, kültürün gerçekleşmesini "bireysel-nesnel kültür" ayrımı, yaşam felsefesini ise "süreç ve form" arasındaki ilişki üzerinden incelemektedir. Simmel, bütün bu kavram çiftlerini, kendi etkileşim anlayışının temellerini ortaya koymak için metodolojik terimler olarak kullanmaktadır. Bütün analizlerinde $o$, parça-bütün ilişkisini üst ilişki olarak göz önünde tutmaktadır. Nihayet ona göre din, parça ve bütün arasındaki ilişkiyi çeşitli biçimlerde özel olarak ele alan sosyal ve kültürel bir biçimdir. ${ }^{26} \mathrm{Her}$ ne kadar Durkheim'ın bir kurucu sosyolog olarak 1899'da “Din Fenomeninin Tanımı Üzerine” başlıklı makalesinde din sosyolojisinden bahsetmesi “ilk

\footnotetext{
24 Simmel, Bireysellik ve Kültür, 47-48.

25 Georg Simmel, Soziologie: Untersuchungen über die Formen der Vergesellschaftung, (Leipzig: Duncker \& Humblot, 1908), 772.

26 Krech, "Die 'Soziologie der Religion'- neu gelesen”, 325; Krech, Georg Simmels Religionstheorie.
} 
olma açısından" meşhursa da Simmel, 1898'de din sosyolojisinden bahsetmekle kalmamış onu kavramsal olarak da tasarlamı̧şır. Aslında Durkheim ve Simmel'ın yaşadıkları yüzyıllar arası geçiş döneminin ruhu, din sosyolojisinin ortaya çıkmasına uygun şartları taşımaktadır. ${ }^{27}$ Simmel, 1906 'da geliştirdiği "Religioiden" kavramıla din sosyolojisinin içeriğini onun din sosyolojisindeki yol gösterici ilkesine uyarlanmış ve bu ilkeye bağl1 kalmışırı. ${ }^{28}$ $\mathrm{O}$, bu kavramla aslında etkileşim sosyolojisinde dinin yerini tayin etmek istercesine "birbirine inanç"ta yatan sosyolojik inanca, dinselliğe dikkat çekmektedir. Ona göre bu inanç, dinselliğin çeşitliliğinin oluştuğu yerdir.

Simmel din sosyoloji yaklaşımında özerk bir kültürel ürün olarak gördüğü din ile sosyalleşme süreçleri arasında analojiler kurmaktadır. Zira ona göre belli dinsel görünümlerle belli sosyal süreçler yapısal olarak karşılaştır1labilir özelliktedir. O, böyle bir yöntemle bütün dinlerin ortak yönlerini tespit etmeyi amaçlamaktadır. Aşağıda ayrıntılı incelenecek olan Din Sosyolojisine Katkı (1898) adlı makalesinde bireyler arası sosyal yaşam biçimlerinin genellikle dini fikirlerin içeriklerini şekillendirdiğini savunmaktadır. Çocuğun ana-babasıyla, vatanseverin vatanıyla olan ilişkisinde yer alan “inanç” Simmel'a göre zaten dinseldir (relgioid). Simmel'ın analojilerine göre sosyal hayatta görülen "birlik" kavramı da tanrısalın tüm maddi bağlarından kopmuş saf bir tezahürüyle ilişkilidir. Simmel için Tanrı tasavvurları da sosyal ilişki biçimlerinin dini sembolleştirilmelerini temsil etmektedir. Nihayet ona göre bireyin grubuyla ahlaki ilişkileri ile bireyin Tanrısı ile ilişkisi arasında benzerlikler bulunmaktadır. Bu benzerliklerde vurguladığ 1 ise "bağımlılık" duygusudur, birey kendisini yükselme ve kurtuluş umduğu kendinden yüksek "bir şeye" bağl1 hissetmektedir. Onun bütün bu analizleri dinî çağrışım yapan sosyal olgular ile dinin kendine özgü dünyasının ortak bir kaynağa sahip olduğu varsayımına dayanmaktadır. ${ }^{29}$ Simmel'ın din sosyolojisinde din; "kökenleri sosyal ilişki biçimlerinde bulunan, kendine

27 Volkhard Krech- Hartmann Tyrell, Religionssoziologie um 1900 (Würzburg: Ergon, 1995).

28 Hartmann Tyrell, "Das Religioide und der Glaube", Georg Simmel und das Leben in der Gegenwart, ed. Rüdiger Lautmann, Hanns Wienold (Wiesbaden: Springer VS, 2018), 347.

29 Volkhard Krech, Religionssoziologie (Einsichten. Themen der Soziologie) (Bielefeld: transcript Verlag,1999), 13. 
özgü sınırları olan hayatın bağımsız bir içeriğidir."30 Bu bakış açısı belirli bir farklılaşma süreci varsayımını gerekli kılmaktadır. Başlangıçta hukuk, bilim, ekonomi, ahlak, sanat ve din gibi tüm bağımsız yapılar iç içe geçmiş görünmekte ancak Simmel'a göre bunlar belli sebep ve amaçlarla farklılaşma süreci yaşamaktadır.

\section{Simmel'in Din Sosyolojisine Katkısı}

Simmel, insan hayatındaki temel bir süreç olarak dini ele alan makalelerinde; din ve dinin modernite, kişilik, sanat, sosyoloji, psikoloji, felsefe ve bilim ile ilişkisi üzerine düşüncelerini ortaya koymaktadır. Söz konusu yazılarında Simmel, din araştırmalarında yöntem konusundaki görüşlerini de aktarmaktadır. Simmel'ın dine ilişkin yazılarında insan deneyiminin fenomenolojik analizi yaşamın öznel boyutları vurgulanarak yapılmaktadır. Simmel, yazılarında kurumsal din ve onun farklı şekillerinden ziyade farklı din biçimlerinden önce gelen, "belirli bir ruhsal nitelik" ya da "ruhun tutumu" şeklinde beliren dindarlık duygusuyla ilgilenmektedir. Din monografisinde dinin bireyin doğayla, kaderle ve toplumla ilişkisi olmak üzere üç alanda tematikleştiğini ortaya koymakta ${ }^{31}$ ve bunlardan üçüncüne yani "insanın insan dünyasıyla ilişkilerine ve bunların içinden akan dinin kaynaklarına” yoğunlaşmaktadır. ${ }^{32}$ Böylece ona göre din, çeşitli bağlamlarda incelenebilecek olan sosyal ilişkilerin bir niteliği olmaktadır.

Simmel, genel felsefi tutumu ve sosyoloji anlayışı doğrultusunda dinin kökeni ve özü konusuna sadece çözülmesi gereken bir sorun olarak yaklaşılmasının aydınlatıcı olmayacağını düşünmektedir. Ona göre 19. Yüzyılın sonunda din konusunda yapılan, bütün dinlerin ortak nihai doğasını tanımlamak yerine dine dair fenomenleri, belli belirsiz genellemelerle betimlemektir. Hâlbuki din olgusu ne metafizik spekülasyona ne de hayaletlere inanmaya indirgenebilir. Dinin doğasının bu şekilde belirlenemez oluşu aslında insanın psikolojik güdülerinin çok çeşitli olmasıyla uyumludur. Din

30 Georg Simmel, “Zur Soziologie der Religion”, Neue Deutsche Rundschau (Freie Bühne) 9 (1898), 113.

31 Georg Simmel, Die Religion,(Dearsbooks Europeachische Literatur Verlag Gmbh, 2014), 5 v.d.

32 Simmel, Die Religion, 22. 
olgusuna oldukça etraflı bir çerçeveden yaklaşan Simmel, dinin içsel kökenine dair ortaya atılan teorilere işaret ederek korku, sevgi, atalara tapma, kendini tanrılaştırma, ahlaki güdüler ve bağımlılık duygusu gibi açıklamaların hiçbirisinin tek başına dinin kökenini açıklayamayacağını ancak bunların her birinin dinin bir kökenini ifade ettiğini belirtmektedir. Böyle bir çoğul durum karşısında ona göre yapılması gereken din alanında bireysel saiklerin ötesinde etkili olan tüm dürtü, fikir ve ilişkilerin bir envanterini çıkararak dinî özün genel yasalarını belirlemektir. ${ }^{33}$

Simmel, insan ilişkilerinin henüz "din" olmayan aşamasına ait dinî doğası üzerine yoğunlaşmaktadır. Burada o, estetik an ile sanat arası ilişkiden yola ç1karak insanlar için dinin yüksek ve saf biçimlerini göstermeyi amaçlamaktadır. Simmel'ın bu doğrultuda ulaştı̆̆ı temel bir nokta dinî duygu ve dürtülerin yalnızca dinde ifade edilmediği, bilakis bunların her türlü bağlantıda, insanlar arasındaki karşılıklı ilişkilerde birçok vesileyle katılan bir unsur olarak kendi bağımsız alanını oluşturduğu tespitidir. Toplum yaşamını oluşturan karşılıklı ilişkilerin her zaman belirli amaçlar, nedenler, çıarlar temelinde ortaya çıktığını belirten Simmel, bu ilişki formlarında dinî olmaktan başka bir şekilde nitelenemeyecek bir içeriğin bulunduğunu savunmaktadır. Onun bakışına göre insanlar arasındaki pek çok ilişki din unsuru içermektedir.

Saygilı çocuğun anne babasıyla, coşkulu yurtseverin vatanıyla ya da coşkulu kozmopolitin insanlıkla ilişkisi; iş̧̧inin yükselen sınıfıyla ya da soylu feodalin kendi sınıfıyla ilişkisi; boyun eğdirilenin, egemenle ve sağcı askerin ordusuyla ilişkisi... Sonsuz çeşitlilikte bir içeriğe sahip tüm bu ilişkiler ona göre dinî olarak nitelemek zorunda olduğumuz ortak bir tona sahiptir. Söz konusu dinî ton insan ilişkilerinde samimiyet, kutsama, bağll llık ve itaat gibi farklı renklere bürünebilmektedir. ${ }^{34}$ Dinsel olan bağımsız ve meşru bir din haline geldiğinde ise insan ilişkilerini bilinçli ve adlandırılmış dindarlık ile etkilemektedir. 35

Simmel'a göre sosyal ilişki biçimlerinden, etkileşimlerden doğan duygusal içerik yoğunlaşıp aşkınlaşarak dinî tasavvurlar dünyası oluşturmaktadır. 
O burada kalmayarak dinin özü olarak nitelediği imanın da her şeyden önce insanlar arası bir ilişki olarak belirdiğini savunmaktadır. Bu doğrultuda Tanrı'ya imanın; onun varlığını -kişi kesin kanıtlayamasa bile- kabul etmekten öte onunla belirli bir içsel ilişki, ona bir duygu bağl1lı̆g, ona doğru bir yaşam yönü anlamına geldiğini belirtmektedir. Simmel'a göre inanç; bir tür bilgi, pratik dürtüler ve duygu durumlarının benzersiz bir karışımıdır. Buradan insanların sosyalleşmesine geçen Simmel, insanların ilişkilerini yalnızca inanç olarak tanımlanabilecek ve pratik koşullar üzerinde etkisi olan belirli fikirler üzerine inşa ettiklerini düşünmektedir. Bu bakışa göre çocuk ebeveynine, ast üste, arkadaş arkadaşa, birey topluma ve köle efendisine inanarak yaşamaktadır. Simmel, onsuz toplumun dağılacağını düşündüğü inancın bu sosyal rolünün hiç araştırılmamış olduğunu vurgulamaktadır. İnancın toplumsal rolüne örnek olarak itaati gösteren Simmel, itaat ilişkisinin çoğunlukla hak ve üstünlüğün kesin bilgisine ya da sevgi veya telkine değil bir insana ya da topluluğa inanmak dediğimiz psişik ara yapıya dayandığını belirtmektedir. $\mathrm{O}$, bu noktada bireylerin ve sınıfların, kendilerini özgürleştirme gücüne sahipken ezilme ve sömürülmeye izin vermelerini "üsttekilerin" gücüne, liyakatine, üstünlüğüne ve iyilik ve hayırseverliğine yönelik eleştirel olmayan inanca bağlamaktadır. ${ }^{36}$ Kısacası Simmel; tüm entelektüel kanıtlara karşı, aksine ne kadar delil olursa olsun bir insana olan inancı, insan toplumunu bir arada tutan en sıkı ve kesinlikle dinî karakterli bir bağ olarak nitelendirmektedir.

Simmel'a göre; önce gelen, din değil sosyal ilişkilerdir. Bu ilişkilerin dinî verilerden azade olarak tamamen bireyler arası saf psikolojik bir ilişkiler olarak ortaya çıktığına inanan Simmel, zamanla bu ilişkilerin kendisini dinî inançta saf ve soyut olarak sergilediğini savunmaktadır. Yani ona göre insan ilişkilerinde sosyal bir gereklilik olarak var olan inanç zamanla, bağımsız tipik insan işlevine dönüşmektedir. İnsan ilişkilerinin günlük yoğun pratiği inancın psikolojik biçiminin çok farklı şekillerini göstermekte ve insanda inanma, inandığıyla bir olma ihtiyacı büyümektedir.

Simmel'ın din teorisinde "birlik" kavramı merkezi bir konuma sahiptir. Ona göre toplumsal bir varlık olan insanın dinsel varlığa evirilmesinde 
birlik kavramı önemli bir işlev görmektedir. İnsan, şeylerin izlenimlerinin birbirinden kopuk çokluğunu basitçe kabul etmek yerine onları bir birlik içinde birleştiren bağlantılarını ve etkileşimlerini aramaktadır. Zira fenomenler karmaşasında yolunu bulmak için her yerde daha yüksek birimlerin ve bireysel fenomen merkezlerinin bulunduğunu varsaymaktadır. Simmel'a göre bu, kesinlikle toplumsal gerçeklikler ve gereklilikler içinde gelişen bir niteliktir. Genlerde, ailede, devlette ve bunlar gibi her maksatlı organizasyonda tek tek öğelerden iş birliği ve göreceli özgürlük esaslı elle tutulur birlikler oluşmaktadır. Kısacası bütünüyle bir "etkileşim" olduğu için tüm sosyal hayat Simmel'a göre; aynı zamanda çoğunluğun birbirine bağlı olduğu, her bir unsurun kaderinin bir diğerini etkilediği bir "birlik"tir. Bu yaklaşımla o; klan gibi gruplarda olduğu gibi toplumun doğasındaki birliğe ve başta tek tanrıllarar olmak üzere dinlerin birlik vurgusuna dikkat çekmektedir. Hatta tanrı fikrinin kendisinin de şeylerin çeşitliliği ve çelişkisini gideren bir birlik içerdiğini hatırlatmaktadır. 37 Kısacası Simmel, toplumsal birlik içgüdüsünün dinde saf, soyut ve esaslı bir biçim aldığını; sapkınlık olarak nitelediği her hareketle enerjik bir şekilde mücadele edişiyle dinin aslında tüm somut bireyselliklerin üzerinde yükselmiş, toplumdaki en saf birlik biçimi olduğunu belirtmektedir.

Simmel, genel din teorisi doğrultusunda birey-grup ilişki ile bireyTanrı ilişkisi arasında analojiler kurmaktadır. Onun bakışınca ikinci ilişki birincisinin yoğunlaşması ve dönüşümünden başka bir şey değilmiş gibi görünmektedir. Birinci ilişkinin tüm gizemli içeriği, ilahi olanı sezdiğimiz etkilerin çokluğunda yansıtılmaktadır. Zorlayıcı ve cezalandırıcı tanrılar, sevgi dolu Tanrı, sevgimize karşılık gösteremeyen Spinoza'nın Tanrı'sı, bize eylem emri veren aynı zamanda bunu gerçekleştirme gücü bahşeden veya bundan mahrum birakan Tanr1...Bütün bu Tanr1 (tasavvur)ları Simmel'a göre, tam da grup ve üyeleri arasındaki etik ilişkinin enerjilerinin ve karşıtlıklarının açığa çıktığı işaretlerdir. ${ }^{38}$ Simmel içinde bütün dinin özünün görüldüğü "bağımlılık duygusuna" (das Gefühl der Abhängigkeit) dikkat çekmekte; bireyin evrensele, aşkın olana, geçmiş kuşaklara, çağ- 
daşlarına olan bağımlılık duygusu ve babanın soyundan gelenler üzerindeki otoritesi ile dinler arasındaki ilişkiye yoğunlaşmaktadır. Onun din teorisinden Tanrı, sosyal bütünlükle eşleşmiş görünmektedir. $O$, Tanrı tasavvurlarına işaret ettikten sonra söz konusu eşleşmeyi şu şekilde ifade eder: "Ĕger açıklanan Tanrı fikrinin özü ... içimizdeki hayat ilgilerinin kaynağında, ayn zamanda birliğinde bulunuyorsa daha fazla uzatmadan toplumsal bütünlü̆̈̈̈ onun yerine koyabiliriz..." "39 Bu bakışla Simmel, kralların tanrısal otoritesini de gücün ellerinde tam olarak yoğunlaşmasının bir ifadesi olarak açıklamaktadır. Zira ona göre bütünün bir parçaya karşı nesneleştirilmesi belirli bir noktaya ulaşır ulaşmaz birey tarafından doğaüstü bir güç olarak kavranmaktadır. Simmel'ın din teorisinde Tanrı tasavvuru ile sosyal birlik o derece karşılıklıdır ki o, incelemesinde her ikisinin tüm sıfat ve işlevlerini birbirine karşı konumlandırmaktadır. Bu yaklaşım ile "...; birlik, ilabi olanın temsil edildiği şseylerin birliğinin kişileştirilmesine kendisini yükselten birlikte yaşayan insanların iliş̧ki biçimi(dir)...; ablak, grubun çıkarlarının onayladığı insan insana ilişski biçimlerini içerir, böylece göreli içerikleri mutlak biçimde sergileyen Tanr, bir yandan grubun iddia ve menfaatlerini bireye karşı temsil eder, diğer yandan da bireyin yerine getirmesi gereken etik-sosyal görevleri yerine getirir ve onları kendi içinde kesinlikle önemli bir biçimde sunar." 40 Simmel'ın analizi sonunda Tanrı ve beşerî olan için yeni bir tanımlamaya ulaşmaktadır: "Tanri'nın mutlak olduğu, insanî olan her şeyin göreceli olduğu şeklindeki eski tasavour burada yeni bir anlam kazanır: Tanrısallık fikrinde tözsel ve ideal ifadesini bulan insanlar arasındaki ilişkilerdir." 41 Simmel, analizin sonlarında aşkınlığ1 içkinliğe indirger görünmektedir.

Simmel'ın din teorisinin günümüzün din fenomenlerini anlamaya katkısı inkâr edilemez. Günümüzün din tartışmalarında; yeni dinî hareketler, ait olmadan inanma, bireysel dindarlık... gibi fenomenlerin anlaşılmasında Simmel'ın erken tespiti değerini korumaktadır: "Manevi bir gerçeklik olarak din; bitmiş bir şey, katı bir madde değill; rivayet edilen içeriğin sarsılmazlı̆̆ına 
rağmen her rubun ve her anın kendisi üretmesi gereken, yaşayan bir süreçtir. Bu süreç; tıpkı sürekli değişen su damlacıklarının gökkusağının sabit görüntüsünü yaratması gibi dinsel olarak mevcut olanı, hareketlerini tekrar tekrar şekillendirmek zorunda olan duygu ırmăgına sürekli çekmeyi gerektirmektedir. İste dinin güç ve derinliği burada yatar." 42

\section{Dindarlıktan Doğan Din}

Gerek "Din" monografisinde gerekse dine dair diğer metinlerinde Simmel, yukarıda işaret edilen çok boyutlu ve katmalı yaklaşım tarzını korumaktadır. Onun metinlerinde psikoloji, kültür ve yaşam felsefesi perspektifleri sosyolojik bir temelde birleşmektedir. Modern toplum koşullarında insanın varoluş biçiminin parçalı doğası ışığında bireysellik sorununu dinî ifadelerle ilişkilendirmeyi amaçlayan Simmel, bireyselliğin sorunlu hale geldiği anlayışını, bireyin sosyalleşme süreçlerine bağımlılığı bilgisiyle yapılan sosyolojik analize ve nesnel kültürün bireysel kültür üzerine kurduğu tahakküme dayandırmaktadır. Simmel, dinsel formun sosyalleşme ile bireyselleşme arasındaki gerilimin belirgin olduğu yerde etkili olduğunu tespit etmektedir. O, bu noktada yukarıda da işaret edildiği gibi “dogmalar”la inşa edilen kurumsal din ile ruh hali ya da öznel dindarlık anlamında dindarlık ayrımı yapmaktadır. 43 Onun bu tutumu genel parça-bütün ilişkisinin bir yansıması olarak görülebilir.

Simmel parça-bütün ilişkisi problemi bağlamında bireyin iki boyutlu toplumsallaşma süreci yaşadığını belirtmektedir. Bu toplumsallaşma iki boyutludur ona göre, zira birey bir taraftan üyesi olduğu bütüne yönelik bir ilişki gerçekleştirmekte diğer taraftan bir üye olarak birey kendisi bütün olmayı talep etmektedir. Bu noktada o, bireyin aşkın bir varlığı temsil eden Tanrı'ya karşı tutumu ile sosyalleşme süreçleri içindeki konumu arasında kurduğu analojiler ile kendi din sosyolojisi perspektifini geliştirmektedir. Bu perspektifle o, bir tarafta "birey ile Tanrı" diğer tarafta "birey ile toplumsal bütün” arasındaki yapısal karşılaştırılabilir ilişkiye

42 Simmel, "Zur Soziologie der Religion”, 123.

43 Volkhard Krech, “Georg Simmel: Die Religion (1906/1912)”, Schlüsselwerke der Religionssoziologie. Veröffentlichungen der Sektion Religionssoziologie der Deutschen Gesellschaft für Soziologie, ed. Christel GärtnerGert Pickel (Wiesbaden: Springer VS, 2019). 
yönelmektedir. Bu bağlamda "inanç" ve "birlik" kavramları söz konusu soyut ilişkileri somutlaştıran kavramlar olmaktadır. Simmel’a göre dinsel kategorinin sosyallik açısından işlevi toplumsallaşma süreçlerinde bireyin bilincinin artması olarak belirmektedir. Öyle ki ona göre toplumsal olarak talep edilen aynı zamanda istikrar ölçüsü, duygusal refakat ve başka türlü elde edilemeyecek bir kutsallık içerir olmaktadır. ${ }^{44}$ Kısacası Simmel, kullandığ 1 analojinin yardımıyla dinsellik formunun hem toplumsallaşma sürecini hem de dinsel anlam dünyasını eş zamanlı içerdiği sonucuna ulaşmaktadır.

Simmel'ın teorisinde dindarlığın dinden daha ön planda oluşunun göstergelerinde birisi de onun, bireyin "bütünlüğe ve kendinden yüksek olana" bağımlılık duygusuna yaptığ1 vurgudur: "Birey kendini içinde aktığı ve kendini bıraktığı genel bir şeye, daha yüksek bir şeye bağl bisseder. Kendisinden farklı ama ayn zamanda onunla özdeş olduğu bu bütün ve yüksek olan, onun için yükselmek istediği ve kurtulus beklediği bir şeydir." 45 Sonuçta Simmel için dinsel olan, eş zamanlı gelişen sosyalleşme- bireyselleşme sürecinde sosyal bir görünüm kazanmaktadır. Zira ona göre dinsel renklere bürünmüş sosyal süreçler, öznenin aynı zamanda içsel ve kişisel bir şey olarak algıladığı daha yüksek bir düzene yönelik bir tutumu olarak belirmektedir. ${ }^{46}$ Böylelikle sosyal süreçlerde şekillenen dinsel kategori aşkınlaşarak ve nesnelleşerek dinin dünyasını kurar. ${ }^{47}$

Simmel'ın dine yaklaşımının bir çeşit ateizm içerdiği söylenebilir. Onun bu yaklaşımının en uygun açıklamalarından biri Peter Berger'in "metodolojik ateizm” olarak nitelediği yöntemdir. Berger, dindar bir Protestan olmakla birlikte dinin insan yaşamındaki yerinin ampirik olarak tespit edilmesinin ve böylece onun beşerî boyutunun ortaya konabilmesinin söz konusu yöntemle mümkün olabileceğini savunmaktadır. ${ }^{48}$

\footnotetext{
${ }^{44}$ Simmel, Die Religion, 30.

45 Simmel, Die Religion, 29.

46 Simmel, Die Religion, 35.

47 Simmel'ın "Religion" monografisinde ortaya koyduğu dinsel olanın toplumsallaşma süreçleriyle iç içe bir şekilde dinin dünyasını inşasının ayrıntılı ve görselleştirilmiş incelemesi için bk. Krech, “Georg Simmel: Die Religion (1906/1912)”.

48 Peter L. Berger, Kutsal Şemsiye: Dinin Sosyolojik Teorisinin Ana Unsurları, çev. Ali Coşkun (İstanbul: Rağbet Yayınları, 2011), 192; 294-306.
} 
Berger' in yöntemine örnek teşkil edecek şekilde Simmel, Tanrı'nın varlı̆̆1 ya da yokluğu meselesiyle ilgilenmemekte dini yalnızca bir bilinç süreci olarak değerlendirmektedir. ${ }^{49}$

Simmel formlar (kategoriler) üzerindeki 1srarıyla dini, dindarlığa dolayısıyla tarihsel ve kişisel fenomenlere indirgemektedir. Onun yaklaşımında din ruhun bir ifadesi, bir bilinç biçimidir. Bu dinsel bilinç bireyin birbirine zıt görünen duygu durumlarına birlik, bütünlük kazandırmaktadır. Bu birlikle tüm duygular Tanrı, doğa ve insanlıkla ilişkide bir ahenk bulmaktadır. Nihayetinde din, Tanrı'da değil tanrısal olanı iç dünyasında deneyimleyen öznenin kurucu etkinliklerinde temellenmekte ve dolayssıla konumunu dindarlığa ve maneviyata terk etmektedir. Simmel'nn ifadesiyle "Dindarlık rubun ses halidir. Kendini özel alanlara yansitır yansıtmaz din haline dönüşür." 50 Dolayısıla "...din dindarlık sürecini hazırlamaz, aksine dindarlık dini meydana getirir." 51 Bu bakışa göre dindarlık bilgi ve eylem biçimi değil, belirli bir duygu eğilimidir.

Dindarlık Simmel'ın din sosyolojisinin merkezi bir kategorisidir ve bireyin dünyaya karşı manevi duruşunu; onun tüm duygu, düşünce, istek ve algılarını şekillendiren temel bir eğilimini ifade etmektedir.52 Eylemler, tutkular ve bütün varlık; bireye dindarlıkla her şeyi ayakta tutan ve onlara birlik veren aşkın bir varlıkla temellenmiş görünmektedir. Dindarlık; özneye ruhun derinliklerinden gelen ve tüm eylemlerine belli bir ahenk veren duygusal yönelimken, tüm nesneler için bir bütünlük ve esenlik ortamı vaat eder. Ruhun bir ifadesi olarak Tanrı'yı arayan ve dünyaya birlik bahşeden manevi bir tutumdur. Böylece dindarlık ampirik görünüşleri; onları aşan daha derin, daha temel bir şeye bağlar; ampirik çokluğu anlamlı bir bütünlükle birleştirir. ${ }^{53}$ Yani dinarlık; görünüş ile öz, parça ile bütün, fizik alem ile metafizik, mümkün olan ile zorunlu olan arasında mistik bir bağlantı kurmaktadır. İnanan her şeyi ilahi varlı̆̆ın bir işareti, göstergesi olarak okumaktadır.

\footnotetext{
49 Vandenberghe, "Immanent transcendence in Georg Simmel's sociology of religion", 7.

50 Simmel, Die Religion, 36.

51 Simmel, Die Religion, 21.

52 Simmel, Die Religion, 14;17-18.

53 Vandenberghe, "Immanent transcendence in Georg Simmel's sociology of religion", 8.
} 


\section{Kişisel Bir Form Olarak Din}

Simmel; bireysel- nesnel kültür ayrımı ile ortaya koyduğu insanın kültür yaratma gücünün bizzat kültür tarafindan etkisiz kılınmasını sürecinin, hayatın geneli için de geçerli olduğunu düşünmektedir. Ona göre hayat ile form arasında, bireysellik ve standartlaşma arasında görüleceği gibi sürekli bir mücadele bulunmaktadır. $\mathrm{O}$, yaşadığı dönemin dinsel hayatında gözlemlediği genel eğilimi de söz konusu mücadele çerçevesinde yorumlamaktadır. 1900'lerin başından itibaren onun gözlemine göre entelektüel açıdan gelişmiş çok sayıda insan, dinsel ihtiyaçlarını mistisizmle karşılamaktadır. Halbuki bu kimseler dönemin etkin kiliselerinin tedrisinden geçmiş kimselerdir. Simmel'a göre bu mistisizm yönelişinin iki temel sebebinden birincisi; bir dizi özgül, nesnel imge aracilı̆̆ıyla dinsel hayatı yönlendiren formların artık o hayat için uygun olmayışıdır. Bu değişimle insanların dinsel ihtiyaçları ortadan kalkmamış; yalnızca bunların karşılanacağı yeni yollar aranmaya başlanmıştır. $\mathrm{Bu}$ arayışta mistisizmin gündeme gelmesi ona göre, mistisizmin dinsel formların katı sınırlarında 1srarcı olmamasından kaynaklanmaktadır. Mistisizm, dogmatik sınırlamaları aşan sınırsız dinsel duyguya imkân tanımaktadır. Böylelikle mistisizm sonsuzluğun derinliğine formsuz kapı aralamakta, ruhun özlemlerini karşılamaktadır. ${ }^{54} \mathrm{Bu}$ sebeplerle Simmel'a göre döneminin aşkın formlarından büsbütün kopmaya hazır olmayan dindarlarının son sığınağı, mistisizm olmaktadır.

Simmel, döneminin dinsel eğilimlerine dair incelemesini sonu mistisizme varan bir evrim süreciyle açıklamaktadır. Ona göre dinsel yapılara da kaynaklık eden içsel hayatın dinsel kültürü bir evrim seyri izlemektedir. Dinsel hayatın doğası ve enerjisiyle uyumlu olan tikel form, belli sınırlar içine sıkışarak zamanla esnekliğini yitirmekte ve yerini dinsel itkinin yeni bir formuna bırakmaktadır. Onun gözlemine göre dinsel kültürün yaşadığ1 evrim sonucu olarak pek çok insan, dinsel ihtiyaçları oradan kalkmamış olmakla beraber inancın öteki dünyaya ilişkin esaslarını reddetmektedir. Söz konusu evrim sonuna kadar götürülse dinsellik; hayatı dolaysız yaşamayı mümkün kılacak, bütün dünyevi boyutlara nüfuz edecektir. Simmel böy-

54 Georg Simmel, Modern Kültürde Catışma, çev. Tanıl Bora, v.d. (İstanbul: İletişim Yayınları, 2015), 75-76). 
le bir incelemeyle geçmişin dinsel yapılarına da ruhunu veren ve değişen formlara rağmen kalıcılı̆̆ını kaybetmeyen, her şeyi kapsayan, kendiliğinden hayat süreci olan dinselliğe dikkat çekmektedir. Öyle ki bu noktada söz konusu olan sahip olma değil "olma"dır; dolayısıyla belli nesnelere sahip olan din yerine hayatın kendi akı̧̧ı içinde varlığı hissedilen, dışsallığı ve ihtiyaçları aşan inançtır. 55

Tinsel hayat ancak formlar içinde ifade bulabilir, formlar içinde gerçekleşebilir. Bu sebeple kilise ile yollarını ayırarak mistisizme yönelen bireyler başa çıkılması zor bir sorunla karşı karşıyadırlar. Bu noktada Simmel kararsızdır, zira temel dinsel bir ihtiyacın mutlaka bir nesneye muhtaç olmadığını söyleyememektedir. Dönemindeki dinsel hayatın özü ona; hayatın gel-gitlerine "rubani bir nitelik katmaktan öteye gitmeyen formsuz bir dinamizmden, tamamen işlevsel bir nitelikten ibaretmiş gibi" görünmektedir. Simmel bu noktada, içsel dinî hayat için kalıcı olamayacak bir ara dönemden bahsetmektedir: mevcut dinsel formları reddetmek ama bunların yerine yenilerini koyamamak. Simmel, -kendinden sonraki sosyal teorisyenlerin modern hayatta dine ilişkin "görünmeyen din" (Luckmann), "kültür olarak din" (Geertz), "modern soyut toplumun işlevsel soyut dini” (Zijderveld)56 gibi yaklaşımlarının öncüsü olacak şekilde- döneminde çok sayıda bireyin dinsel itkinin canlılığı hissetmelerine rağmen kurumsal dini muhafaza edememelerine dikkat çekmekte ve dini dışsal örtüsünden mahrum eden "aydınlanmanın” bile onun varlığına kastedemeyeceğini eklemektedir. Kültürün trajedisinin ressamı Simmel için bu noktada asıl sorun "inanç’in bir nesneyle ilgili olmaktan çıkması”nın uzun vadede çözümsüzlük doğuracak olmasıdır. Zira -din de kendisinin bir ürünü olan- kültürel hayat ya formlar üretmeli ya da verili formlar içinde ilerlemelidir. 57

\section{Kültürel Ürün Olarak Din}

Simmel incelemesine toplum, birey ve kültürün farklılaşmadığı "bir andan” başlamaktadır. Varlıklar aralarındaki etkileşimle yavaş yavaş bir yapı

\footnotetext{
55 Simmel, Modern Kültürde Çatı̧sma, 77.

56 Adı geçen teorisyen ve yaklaşımları için bk. Cevat Özyurt- Ejder Okumuş (ed.), Caăgdaş Sosyal Teoride Din (Ankara: Hece Yayınlar1, 2016).

57 Simmel, Modern Kültürde Çatışma, 77-78.
} 
oluşur. Bilincin belirdiği bu süreçte insanlar, semboller kullanma ve kültürel üretimle diğer canlılardan farklarını ortaya koyarlar. Kültür hem bilinçli eylemin bir koşulu hem de bir ürünüdür. Simmel, kültürü diyalektik bir nesnelleştirme ve özneleşme süreci olarak görmekte, form ve içerik diyalektiğini kullanarak kültürel farklılaşmayı ortaya koymaktadır. Formlar içinde ilerlemek durumunda olan kültürel hayatın bir ürünü olarak dine ait içeriklerin sosyal bir forma girebilmesi gibi dinî formlar da sosyal etkileşimleri yapilandırabilmektedir.

Simmel'a göre bireyler arasındaki sosyal etkileşimlerden birlik duygusu oluşmakta, bu birlik duygusu gökyüzüne yansıtılıp idealleştirilmekte ve toplumsal grubun birliğini temsil ve icra eden Tanrı ile sembolize edilmektedir. Bu süreçte etkileşimlerden kaynaklanan sosyal birlik bir şekilde yükselmekte ve grubun arzuladığı ancak gerçekte asla elde edemediği, birliği saf biçimde sembolize eden toplum dışı bir töze dönüştürülmektedir. Böylece etkileşim halindeki bireyler dinde kendilerinin bilincine varmakta, ardından din de kendi bilincine ulaşmakta ve bu üçüncü düzeyde kültürel anlamların farklılaşmamış kaynağından özel bir form olarak ortaya çıkmaktadir.

Simmel'ın incelemesine göre sosyal dayanışmanın sürdürülmesiyle oluşan ve yarı dini bir özellik gösteren birlik duygusu, zamanla dine evrilmektedir. Ona göre din, zaten psişik enerjilerin özerk bir kültürel formda kristalleşmesinden başka bir şey değildir. Bu süreçte sosyal etkileşimlerin kendi bilincine vararak nesnelleşmesi olarak beliren olgu; kendine has yasalara ve mantığa sahip, sistemleştirilebilen ve daha da geliştirilebilen bir nesnel içerikler kompleksi olmaktadır. Böylelikle özerk bir kültürel form olarak ortaya çıkan din; felsefe, etik, estetik, hukuk, bilim ve teknoloji gibi diğer kültürel formlardan ayrışmakta ve kendine has kurallarıyla işlemektedir. 58 Bütün bu çözümlemelerde felsefe ile sosyoloji belli bir noktada kesişmekte, dinin toplumsal hayattan kültürel bir form olarak doğuşunun analizinde sosyoloji iş görürken onun metafizik içeriğiyle felsefe ilgilenmektedir.

Simmel'a göre insanlar; çözümlenemez varlı̆̆ı, kendine has kuvvet ve amaçlılı̆̆ıyla dolaysız hayatın yalnızca belli bir andaki tikel formuna sahip-

58 Vandenberghe, “Immanent transcendence in Georg Simmel's sociology of religion”, 14-15. 
tirler. Bu dolaysız hayattan doğan form, kendine has meşruiyeti ve hukukuyla meydana geldiği andan itibaren farklı bir düzenin parçası olmakta; hayatın özüne, taşkın dinamizmine rağmen onun ötesinde bir varoluşa sahip olmayı talep etmektedir. Bu durumda hayatın formdan yoksun kuvveti ile katı, bağımsız ve zamandış11ı iddiasındaki formun karşı karşıya geldiği bir paradoks oluşmaktadır. Bu paradoks kültürün ilerlemesi ölçüsünde derinleşmektedir. Zira hayatın yönettiği bilgi, irade ve yaratımın elinden bir formun yerine bir başkasını koymaktan başka bir şey gelmemektedir. ${ }^{59}$

Yukarıda da işaret edildiği üzere hayatın kültürel ürünlerinden biri olan dinin kurumsallaşmış formlarına yönelik çeşitli motivasyonlarla yapılan ve yapılacak tüm "saldırılar" da Simmel'ın bakışı açısından tinin kültüre dönüşmesinden kaynaklanan derin çelişkilerin tezahürleri olarak görünmektedir. Modern dönem, insanlık tarihinde söz konusu çelişkinin keskinleşip hayatın bütününü etkilediği dönemlerin en belirgin olanıdır. Ancak hayatın tarihi ve düzenlenişi içindeki çatışmaların mutlak bir şekilde çözülmesini beklemek de doğru değildir. Zira söz konusu çatışma ve sorunların çözümden bağımsız olarak yerine getirdikleri işlevleri bulunmaktadır.

\section{Sosyalleşme Formu Olarak Din}

Simmel'ın sosyolojisine göre birbirinin bilincinde olan en az iki kişinin etkileşimde olduğu durumlarda toplumun örgüsünün ilmekleri ortaya çıkmaktadır. İki kişi oyun oynadığında, üç kişi birlikte yemek yediğinde bu eylemler, içerisinde birçok ritüelin icra edildiği sosyalleşme formlarını oluşturmaktadır. Bu ve benzeri eylemler her halükârda birlikte "biz" duygusunun oluştuğu birleşik eylemlerdir ve sona erdiklerinde bireyler arkalarında mikro toplum tecrübesi bırakmış olurlar. Bu yaklaşıma göre toplum, bireyler arasındaki sürekli etkileşim akışından oluşmaktadır. Buradaki etkileşim akışı belli bir süreci ifade etmektedir ve bu mikro toplumlar Simmel tarafindan "Vergesellschaftungen" (sociations) olarak adlandırilmaktadır. Aslında burada söz konusu olan Durkheim'ın "birlikler"60, Weber'in "top-

59 Simmel, Modern Kültürde Çatı̧ma, 79-81.

60 Emile Durkheim, Sosyoloji Dersleri, çev. Ali Berktay (İstanbul: İletişim Yayınları, 2006), 113. 
lumsal ilişkiler"61 olarak adlandırdığı yapılardır. Simmel'ın mikro sosyolojisinde sosyalleşmenin kriteri bireylerin birbirleriyle, birbirleri için veya birbirlerine karşı yönelimleridir. Toplumda bu yönelimlerin bulunduğu her yerde bireyler sosyal gruplar oluşturur, bunlar geçici ancak toplum kalıcıdır. Simmel'a göre toplum, birbirleriyle etkileşime giren bireylerin karmaşık, sürekli değişen ve geçici sosyalleşmeler ağıdır.

Simmel'ın mikro sosyolojisine yemek, öğün birliktelikleri üzerine yazdıkları örnek verilebilir. İnsanlar birlikte yemek yerken ihtiyaç karşılamanın ötesinde daha yüksek kültürel bir etkinliğe girişmektedirler. Yemek yemenin yazılı olmayan belli görgü kuralları, estetik tercihler bulunmaktadır. Bireyler birlikte yemek yerken kasıtll, ortak bir bilinç taşıyan bir eylem gerçekleştirmektedirler. Simmel; yemeğin birleştirici yönüne dikkat çekerek antik çağ kültlerindeki kurban yemeklerini, Sami antik çağındaki kardeşçe birlikte yemeğin Tanrı'nın rızasına muvafik oluşunu ve Arap kültüründe düşmanla birlikte yemek yemenin anlamını örnekler olarak sıralamaktadır. Ancak o, ekmeği İsa'nın bedeniyle özdeşleştiren Son Akşam Yemeği'ni, bu yemeğin mistisizm temelinde katılanlar arasında benzersiz bir bağlantı türü yaramasını özellikle vurgulamaktadır. Zira burada ona göre herkesin birbiriyle eşit olarak paylaşılan "gizemli bölünmezliği" paylaşma ve kendi için tüketmenin egoizminin açık şekilde aşılması söz konusudur. Fizyolojik ilkellik ve kaçınılmaz genellik olarak sıradan yemek burada toplumsal etkileşim alanına, dolayısıyla kişi-ötesi öneme taşınmaktadır. ${ }^{62}$ Sosyal bir birliktelik biçimi olarak yenen yemek "kutsal komünyon" ile çok farklı bir görünüm kazanmaktadır. Papazın etrafında toplananlar, kutsanmıs ekmeği yiyerek Mesih aracılığıyla kalben ve zihnen iletişim kurmaktadırlar. Mesih'in manevi mevcudiyeti sayesinde, her inanan doğrudan Tanrı ile ve dolaylı olarak diğer inananlarla iletişim kurmaktadır. Simmel sosyolojisine göre aktörler arasındaki kalp ve zihin iletişimi nihayetinde toplumu oluşturan şeydir ve Tanrı da zaten inananları bir araya toplayan varlıktır.63

\footnotetext{
${ }^{61}$ Max Weber, Sosyolojinin Temel Kavramları, çev. Medeni Beyaztaş (İstanbul: Bakış Yayınları, 2007), 50-51.

62 Georg Simmel, “Soziologie der Mahlzeit”, Der Zeitgeist, Beiblatt zum Berliner Tageblatt Nr. 41 (10 Oktober 1910), 1-2.

63 Simmel, Die Religion, 53.
} 
Simmel'in perspektifinde toplum, gruba katilan ve grupta yer alan ve bunu yapmanın bilincinde olan tüm insanlar tarafından yaratılan katılımc1 bir gerçekliktir. Bu haliyle toplum, ikinci dereceden bir tür bilince, bir etkileşim içinde olan bireylerin bilincine dayanmaktadır. Ancak bireyler yalnızca bir araya geldiklerinde değil, sahip oldukları çağrışım gibi çeşitli "araçlarla" her zaman bu bilinci taşımaktadırlar. Simmel'ın mikro ölçekteki analizi makro düzeye taşınmaya müsait görünmektedir. Yalnız başına dua ederek Tanrı'yla konuşan mümin, aynı zamanda inanan kardeşlerinin oluşturduğu birliğin bir parçası olduğunu duyumsamaktadır.

\section{Sonuç}

Simmel; Durkheim ve Weber gibi sosyolojinin kurucu figürleri ile aynı dönemde yaşamış olmasına; kapitalizm ve kentleşmenin yol açtığı büyük toplumsal değişmelere onlar gibi tanık olmasına ve benzer bilim felsefesi kaynaklarından beslenmesine rağmen onlardan farklı bir din teorisi geliştirmiştir. O geliştirdiği din teorisi yaklaşımıyla günümüz din sosyolojisinde geniş kabul gören önemli kuramsal yaklaşımların erken bir habercisi olmuştur. Ancak sosyolojik kuramların geliştirilmesinde, sosyoloji disiplininin kurumsallaşmasında diğer kurucu sosyologlar kadar öncü ve önemli katk1larına rağmen Simmel'ın din sosyolojisine katkısı yeterince işlenmemiştir. Bunda Simmel'ın din teorisinin felsefî yanlarının sosyolojik yanlarından fazla olması, bütüncül ve tutarlı bir din sosyoloji ortaya koymamış olması, konuları ile ilişkili malzemenin dağınıklığı, uyumlu genel açıklamaların azlığı ve akademik geleneğe aykırı duruşu etkili olmuştur.

Simmel'ın din teorisi dikkatle incelendiğinde onda; Batı'da 1960'lı yıllardan itibaren iyice yerleşen çağdaş din sosyolojisinin felsefî, fenomenolojik, antropolojik, nitel ve hümanist çizgisinin öncü işaretlerini bulmak mümkündür. Onun din anlayışı; günümüz din sosyolojisinin dini, hayatın geri kalanından ayırmayan ve insan yaşam biçiminin ayrılmaz bir parçası olarak gören yaklaşımına paralel konumlanmaktadır. Yine Simmel'ın din teorisine ilişkin yöntemi de aynı doğrultuda inançları paranteze alan bir nesnellik arayışı içinde olması açısından öncü bir nitelik arz etmektedir.

Simmel'ın din anlayışında insanın birlik, bütünlük arayışı ve dindarlık eğilimi merkezi bir konuma sahiptir. $\mathrm{O}$, tanrısallı̆̆ da bunlarla ilişkilen- 
dirmekte ve tanrısal olanın deneyimlenebilecek olmasına karşın tarif edilemez, tanımlanamaz olduğunu özellikle vurgulamaktadır. Böylece Simmel, Tanrı'nın varlığ1 ya da yokluğu meselesini inceleme dışı bırakarak dini yalnızca bir bilinç süreci olarak değerlendirmektedir. Onun bu tavrı aşkın olanı içkinde arayan bir görünüm arz etmektedir. Simmel'ın yaklaşımında din dindarlığa dolayısıyla tarihsel ve kişisel fenomenlere, bir bilinç biçimine indirgenmekte; Tanrı'da değil de tanrısal olanı iç dünyasında deneyimleyen öznenin kurucu etkinliklerinde temellendirilmektedir.

Simmel'ın din teorisi; sosyoloji, kültür teorisi ve yaşam felsefesi katmanlarına dayanan ve sistematik olmayan bir teoridir. Geliştirdiği "Religioiden" kavramıyla "birbirine inanç"ta yatan sosyolojik inanca, dinselliğe dikkat çekmiştir. O, kurumsal din ve onun farklı şekillerinden ziyade farklı din biçimlerinden önce gelen, "belirli bir ruhsal nitelik" ya da "ruhun tutumu" şeklinde beliren dindarlık duygusuna odaklanmıştır. Ona göre bu inanç, dinselliğin çeşitliliğinin oluştuğu yerdir. $\mathrm{O}$, insan doğasında orijinal bir eğilim, özel içsel bir mizaç olarak dindarllğıın kültürün içinde gelişerek somut bir gerçekliğe, dine dönüştüğü savunmuştur. Yani ona göre kurumsal din, uzun süreli kişilerarası etkileşimler ardından ve çok sayıda etkileşimsel tecrübeler vasıtasıyla ortaya çıkan kültürel bir üründür.

Simmel din ile sosyalleşme süreçleri arasında analojiler kurarak bütün dinlerin ortak yönlerini tespit etmeyi amaçlamıştır. O, bireyler arası sosyal yaşam biçimlerinin genellikle dini fikirlerin içeriklerini şekillendirdiğini savunmuştur. Ona göre tanrı tasavvurları sosyal ilişki biçimlerinin dini sembolleştirilmelerini temsil etmekte ve bireyin grubuyla ahlaki ilişkileri ile bireyin Tanrısı ile ilişkisi arasında benzerlikler bulunmaktadır. Kısacası o, dinin kökenlerini sosyal ilişki biçimlerinde aramı̧̧ır.

\section{Kaynakça}

Coser, Lewis A. Georg Simmel (1858-1918). Masters of Sociological Thought, Ideas in Historical and Social Context. New York: Harcourt Brace Jovanovich, 2. Basım, 1977.

Berger, Peter L. Kutsal Şemsiye: Dinin Sosyolojik Teorisinin Ana Unsurları. çev. Ali Coşkun. İstanbul: Rağbet Yayınları, 4. Basım, 2011.

Cipriani, Roberto. Din Sosyolojisi, Tarih ve Teori. haz: Ali Coşkun. İstanbul: Rağbet 
Yayınlar1, 2014.

Durkheim, Emile. Sosyoloji Dersleri. çev. Ali Berktay. İstanbul: İletişim Yayınları, 2006.

Durkheim, Emile. Dinsel Hayatın İlkel Biçimleri. çev. Fuat Aydın. Ankara: Kalkan Matbaacilik, 2011.

Durkheim, Emile. Toplumsal I̦şbölümü. çev. Özer Ozankaya, İzmir: Cem Yayınevi, 2018.

Frisby, David. Georg Simmel. London: Routledge, 2. Basım, 2002.

Frisby, David. Modernlik Fragmanları Simmel, Kracauer ve Benjamin’in Eserlerinde Modernlik Teorileri, çev. Akın Terzi. İstanbul: Metis Yayınları, 2012.

Frisby, David. "Georg Simmel: Modernitenin İlk Sosyoloğu”, çev. Elçin Gen, Modern Kültürde Çatışma. haz. Elçin Gen. 9-51. İstanbul: İletişim Yayınları, 2015.

Winfried Gebhardt, "Religionssoziologie". Handbuch Spezielle Soziologien. ed. Georg Kneer, Markus Schroer. 393-404.Wiesbaden: VS Verlag für Sozialwissenschaften, 2010.

Geoghegan, Vincent. "Religion and communism: Feuerbach, Marx and Bloch". The European Legacy 9/5, (2004), 585-595. https://doi. org/10.1080/1084877042000306352

Krech,Volkhard -Tyrell, Hartmann. Religionssoziologie um 1900. Würzburg: Ergon, 1995.

Krech, Volkhard. Georg Simmels Religionstheorie (Religion und Aufklärung 4). Tübingen: Mohr Siebeck, 1998.

Krech, Volkhard. Religionssoziologie (Einsichten Themen der Soziologie). Bielefeld: transcript Verlag, 1999.

Krech, Volkhard. "Die 'Soziologie der Religion'- neu gelesen”. Georg Simmel und das Leben in der Gegenwart. ed. Rüdiger Lautmann, Hanns Wienold. 325346. Wiesbaden: Springer, 2018. https://doi.org/10.1007/978-3-658$\underline{21427-2 \quad 18}$

Krech, Volkhard. “Georg Simmel: Die Religion (1906/1912)”. Schlüsselwerke der Religionssoziologie. Veröffentlichungen der Sektion Religionssoziologie der Deutschen Gesellschaft für Soziologie. haz. Christel Gärtner, Gert Pickel. 109119. (Wiebaden: Springer VS, 2019. https://doi.org/10.1007/978-3-65815250-5_14 
Özyurt, Cevat - Okumuş, Ejder (ed.). Çağdaş Sosyal Teoride Din. Ankara: Hece Yayınlar1, 2016.

Ritzer, George. Klasik Sosyoloji Kuramları. çev. Himmet Hülür. Ankara: De Ki, 2011.

Simmel, Georg. "Zur Soziologie der Religion". Neue Deutsche Rundschau (Freie Bühne) 9 (1898), 111-123. https://socio.ch/sim/verschiedenes/1898/religion.htm

Simmel, Georg. Soziologie: Untersuchungen über die Formen der Vergesellschaftung. Leipzig: Duncker \& Humblot, 1908.

Simmel, Georg. "Soziologie der Mahlzeit". Der Zeitgeist, Beiblatt zum Berliner Tageblatt Nr. 41 (10 Oktober 1910), 1-2. https://socio.ch/sim/ verschiedenes/1910/mahlzeit.htm

Simmel, Georg. Bireysellik ve Kültür. çev. Tuncay Birkan. İstanbul: Metis Yayınları, 2009.

Simmel, Georg. Die Religion. b.y.: Dearsbooks Europeachische Literatur Verlag Gmbh, 2014.

Simmel, Georg. Modern Kültürde Çatışma. çev. Tanıl Bora, v.d. İstanbul: İletişim Yayınları, 2015.

Susman, Margarete. Die geistige Gestalt Georg Simmels. Tübingen: Mohr + Bdd, 1959.

Taştan, Abdulvahap- Aksoy, Mehmet. "Georg Simmel'in Sosyolojik ve Psikolojik Bakış Açılarından Din ve Dindarlık Anlayışı”, Bilimname, 2020 / 41 (May1s, 2020), 39-65. https://doi.org/10.28949/bilimname.682876.

Tyrell, Hartmann. "Das Religioide und der Glaube". Georg Simmel und das Leben in der Gegenwart. ed. Rüdiger Lautmann, Hanns Wienold. Wiesbaden: Springer VS, 2018, 347-362. https://doi.org/10.1007/978-3-658-21427-2 19

Vandenberghe, Frederic. "Immanent transcendence in Georg Simmel's sociology of religion". Journal of Classical Sociology 10/1, (February 2010), 5-32. https://doi/10.1177/1468795X09352559

Weber, Max. Protestan Ablakı ve Kapitalizmin Rubu. çev. Zeynep Gürata. İstanbul: Ayraç Yayınları, 1999.

Weber, Max. Sosyolojinin Temel Kavramları. çev. Medeni Beyaztaş. İstanbul: Bakış Yayınları, 2007. 